\title{
Current Status of Fungal Diseases on Swarna Cultivar (MTU 7029) of Rice in Gangetic Alluvial Zone of West Bengal, India
}

\author{
Vikas Kumar Ravat* and Amitava Basu
}

Department of Plant Pathology, Bidhan Chandra Krishi Viswavidyalaya, Mohanpur Nadia,

West Bengal - 741252, India

*Corresponding author

\section{A B S T R A C T}

A survey was conducted on Swarna cultivar (MTU 7029) of rice during Kharif 2013, 2014, 2015 and 2016 at Nadia district of West Bengal to record the fungal disease and

Keywords

Rice, Yield, Growth stages,

Temperature,

Kharif, Nadia,

West Bengal.

Article Info

Accepted:

21 August 2017

Available Online:

10 September 2017 their respective yield loss. Ten diseases (Leaf blast, Sheath blight, Sheath rot, Brown spot, Brown Leaf Spots caused by Curvularia lunata, Stackburn disease, Leaf spot caused by Nigrospora oryzae, Stem rot, Rotting by Choanephora cucurbitarum and False smut) were based on visual observation on Swarna rice cultivar and yield loss due to respective disease was calculated by measuring test weight $(\mathrm{gm})$ of rice grains. Leaf blast was noticed in mild form at Madanpur whereas, Sheath blight were noticed in severe form at Jaguli and Chakdah. Among eight spots (Madanpur, Jaguli, Gayeshpur, Kalyani, Chakdah, Ranaghat, Santipur and Krishnagar) of Nadia district, the disease incidence of sheath rot was recorded maximum at Jaguli and Kalyani, while moderate infection was observed at Chakdah and Santipur. Brown spot was more severe at Chakadah and Jaguli. Mild and trace infection was recorded due to Leaf spot caused by Nigrospora oryzae, stem rot and rotting caused by Choanephora cucurbitarum and the false smut was more severe at Jaguli. Two bio metrological parameters (Temperature and relative humidity) were recorded during Kharif 2013, 2014, 2015 and 2016. The different diseases were favoured by different growth stages of rice.

\section{Introduction}

Rice (Oryza sativa L.) a member of family Gramineae, is cultivated throughout the world and is a staple food crop of 60 per cent of the world's population. After China, India is the second largest producer of rice in the world. In India, rice crop is grown under wide range of agro-climatic conditions and is being cultivated over an area of $44.40 \mathrm{~m}$ hectares with total production of $104.32 \mathrm{~m}$ tonnes during 2011-12 (Anonymous 2013). The major rice growing states of India are West Bengal, Bihar, Madhya Pradesh, Orissa,
Andhra Pradesh and Uttar Pradesh where rice is grown over more than 65 per cent of the total cultivated area. Swarna rice cultivar (MTU 7029) is most commonly recommended by farmers due to its high yield but, now-a day, the scenario of rice diseases is changing due to extensive use of chemical fertilizers, pesticides and high yielding cultivars. The minor diseases like, false smut, bakanae, sheath rot and grain discoloration which were of less significance earlier, are now emerging as serious threat to rice 
cultivation (Gupta et al., 2015). Ravat et al., (2015) reported Choanephora cucurbitarum in rice from West Bengal, India and mentioned that due to climate change some minor pathogen are replacing major one and causing severe devastation under favourable environmental condition. Keeping above point in consideration, a survey had been carried out in Gangetic Alluvial Zone of West Bengal for observing fungal diseases status of Swarna cultivar (MTU 7029) and their economic significance.

\section{Materials and Methods}

Experimental rice plots and farmers field were surveyed for four months in Kharif season of every year and the disease incidence was recorded at 7 days interval in Nadia district of West Bengal. The 24 sites were selected from 8 different (3 from each place) rice growing areas (Madnapur, Jaguli, Gayeshpur, Kalyani, Chakdah, Ranaghat, Santipur and Krishnagar) of Nadia district. The survey was conducted in the cropping period during the Kharif 2013, 2014, 2015 and 2016.

At each site 12 rice fields were selected and nine spots were thoroughly examined (The four corners, midway along each edge and at the centre). Visual scoring of incidence and severity of disease (0-9 scale for Blast, Sheath blight, Sheath rot, False smut, Brown spot and Grain Discoloration, 0-5 scale for stem rot of rice) was done using the International Rice Research Institute (IRRI) standard evaluation scale (IRRI, 1996). PDI and Disease incidence were calculated by using the following formulas given by Wheeler (1969) and Hajano et al., (2011):

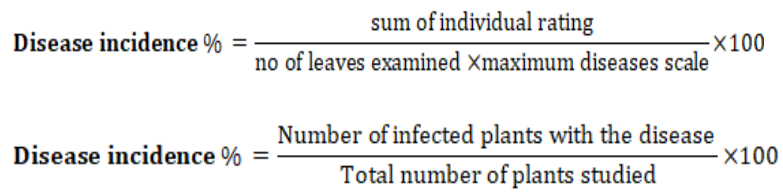

The PDI observation was taken with the help of the standard disease rating scale, which is different for different sheath infecting pathogen. At harvest, the number of normal and infected grains per tiller, 1000-grain weight, and the yield per plot were also recorded. 100 infected panicles from each field were selected for observation.

Daily weather data on Temperature $\left({ }^{\circ} \mathrm{C}\right)$ and Relative humidity (\%) were collected from Agrometrology Department, Faculty of Agriculture, Bidhan Chandra Krishi Viswavidyalaya, West Bengal.

\section{Results and Discussion}

\section{Symptomatology study of fungal foliar disease}

Ten diseases namely Leaf blast, Sheath blight, Sheath rot, Brown spot, Brown Leaf Spots caused by Curvularia lunata, Stackburn disease, Leaf spot caused by Nigrospora oryzae, Stem rot, Rotting by Choanephora cucurbitarum and False smut were found during survey of Kharif 2013, 2014, 2015 and 2016 on Swarna rice cultivar. The blast fungus produces spots or lesions on leaves (Figure 2I), nodes and different parts of the panicles and the grains. The leaf spots are typically elliptical with more or less pointed ends. The centre of the spots is usually grey or whitish with brown or reddish-brown margin. Typical spots of brown spot (Figure 2J) Are found on the leaves. They are oval shaped and relatively uniform and evenly distributed over the leaf surface. The spots are brown, with grey or whitish centres about the size of sesame seeds. Young or undeveloped spots are small and circular and may appear as dark brown or purplish brown dots. Typical stack burn disease symptom on the leaves (Figure 1A and B) are large, oval or circular, with dark brown, relatively narrow and distinct margins which circle the spots like a 
ring. The centre of the spot is first pale brown, gradually becoming almost white and bearing minute black dots and sometimes surrounded by a second ring. Usually only a few spots on a few leaves are observed in the field. The first sign of stem rot (Figure 3P) of rice is a small, blackish, irregular lesion on the outer leaf sheath near the water line that was followed by sclerotia formation. The lesion first enlarged, then penetrates the inner leaf sheath, and finally the leaf sheath is partially or completely rotted. After penetrating the inner leaf sheath, infection reached to the culm, where numerous infection cushions are found on the outer surface of culm. Brownishblack lesions is developed on the culm and one or two internodes of the stem are eventually rotted and further collapsed (only the epidermis remains intact), resulting lodging, formation of chaffy grains, and death of the tiller.

The spots of sheath blight (Figure 3M, N and O) are at first ellipsoid or ovoid, somewhat irregular. Greenish-grey, varying from 1 to 3 $\mathrm{cm}$ long. The centre of the spot becomes greyish-white, with a brown margin. Sclerotia is formed on or near these spots but are easily detached. The size and colour of spots and the formation of sclerotia depend upon environmental conditions.

The sheath rot occurs on the uppermost leaf sheaths (Figure $2 \mathrm{~K}$ and L) enclosing the young panicles. The lesions start as oblong or somewhat irregular spots. $0.5-1.5 \mathrm{~cm}$ long, brown margins and grey centres. The spot enlarged and coalesce, covered the leaf sheath. An abundant whitish powdery growth was found inside affected sheaths and young panicles were rotted. The Ustitaginoidea virens fungus transforms individual grains of the panicle (Figure 1C and D) into greenish spore balls or a velvety appearance. The spore balls are small at first and are visible in between the glumes, growing gradually to reach $1 \mathrm{~cm}$ or more in diameter and enclosing the floral parts, they are smooth, yellow and are covered by a membrane. The membrane bursts as the result of further growth and the colour of the ball becomes orange and later yellowish-green or greenish-black. Symptoms of Curvularia lunata first symptoms (Figure $1 F)$ appeared on the leaves. Elliptical brown spots are observed. The spots increased in size on leaves. Gradually the colour of the spots changed to brownish black. The length of spots ranged from 0.2 to $1 \mathrm{~cm}$. Later the spots appeared on leaf sheath which are dark brown initially with yellow margin and the diseased sheath became yellow and blighted. Initially these spots are similar to the ones on the leaf but later covered the whole leaf sheath. Gradually the disease spread to the kernels. Glumes were discoloured and in severe infection, the rice kernel showed black discoloration. Symptoms of Choanephora cucurbitarum appear as brown spots on the leaf blade (Figure 1E) and on the small emerging leaves. Primary symptoms are brown small, round-ovoid spots with a chlorotic halo, evenly distributed over the leaf. The size of spots varies from $0.1 \mathrm{~cm}$ to 1 $\mathrm{cm}$. Over time, spots merge and become large. Symptoms of Nigrospora oryzae range from small lesions (Figure $2 \mathrm{G}$ and $\mathrm{H}$ ) that are chocolate brown and oval or circular up to withered leaves.

Yield loss scale (formulated during present research work)

\begin{tabular}{|c|c|}
\hline Score & Description \\
\hline $\mathbf{0 - 2 0 \%}$ & Mild \\
\hline $\mathbf{2 1 \% - 4 5 \%}$ & Moderate \\
\hline $\mathbf{> 4 5 \%}$ & Severe \\
\hline
\end{tabular}


Fig.1 Symptoms of (A) Stackburn, seedling blight at early stage (B) Stackburn, seedling blight at later growth stages, (C) and (D) False smut, (E) Rotting by Choanephora cucurbitarum and (F) Brown Leaf Spots by Curvularia lunata
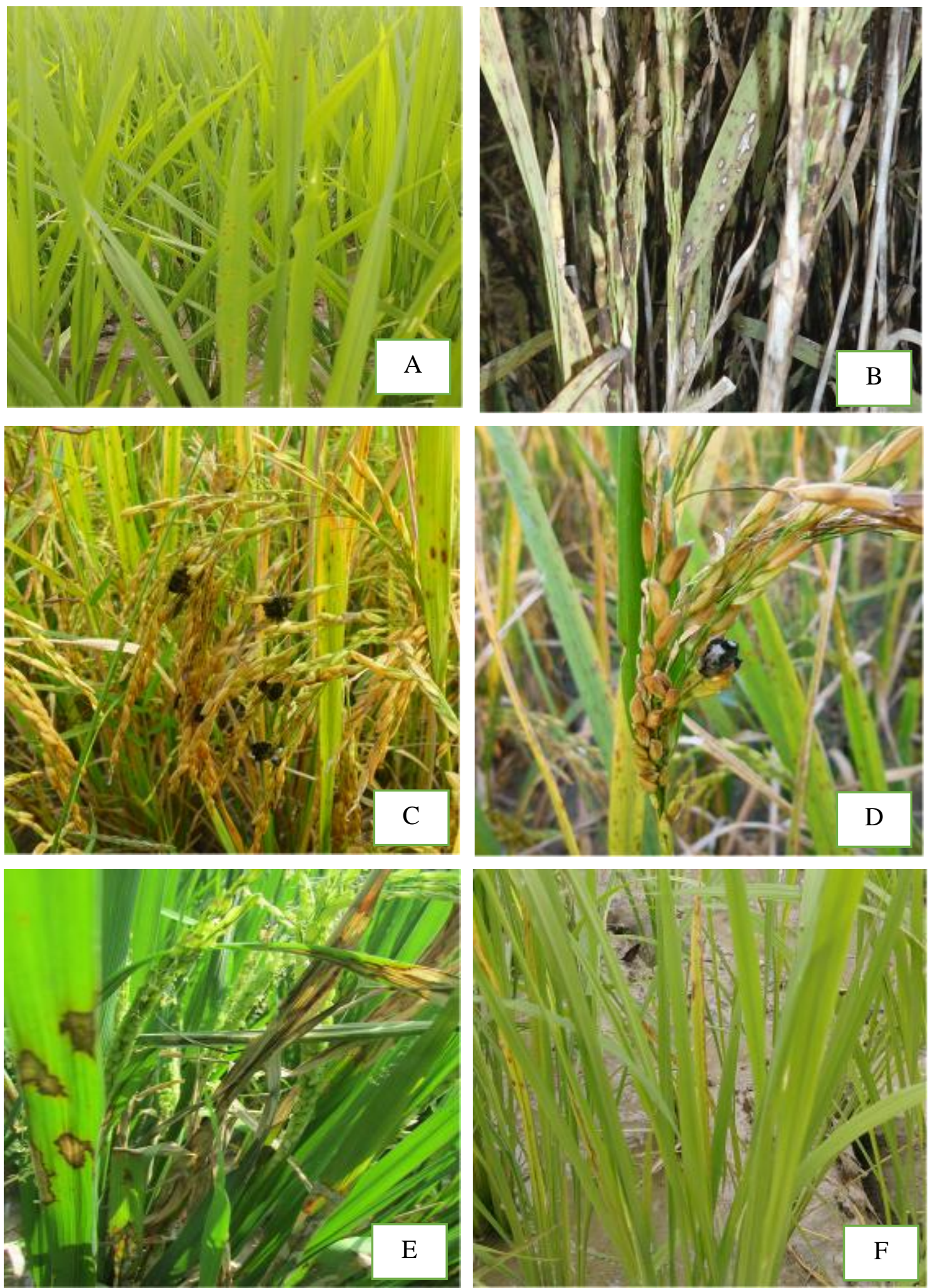
Fig.2 Symptoms of (G) and (H) Leaf spot by Nigrospora oryzae, (I) Foliar blast, (J) Brown spot, (K) and (L) Sheath rot
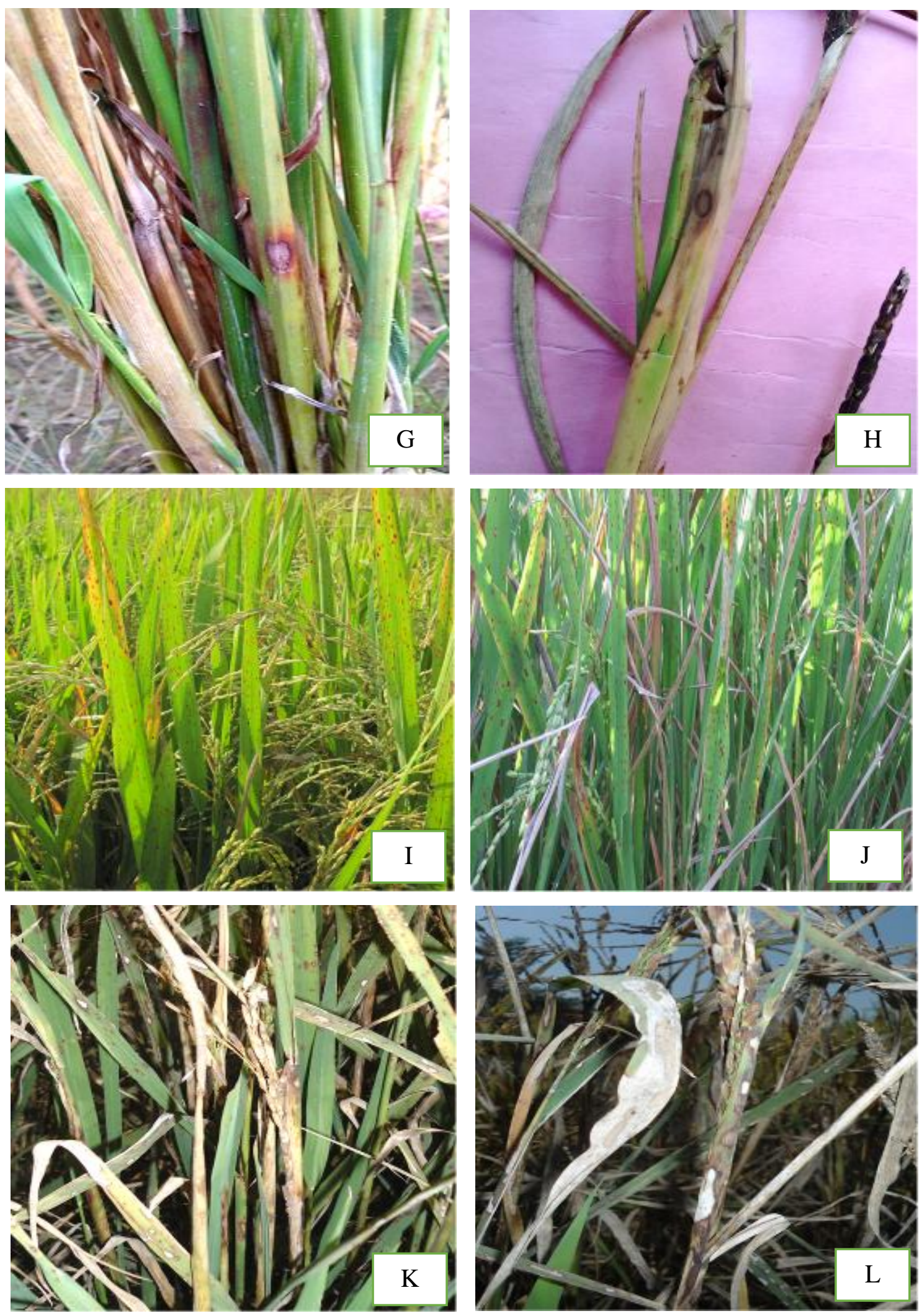
Fig.3 Symptoms of (M) and (O) Sclerotia of Rhizoctonia solani on field, (N) sheath blight symptom on rice plant, (O) Sclerotia of Sclerotium hydrophilum on field
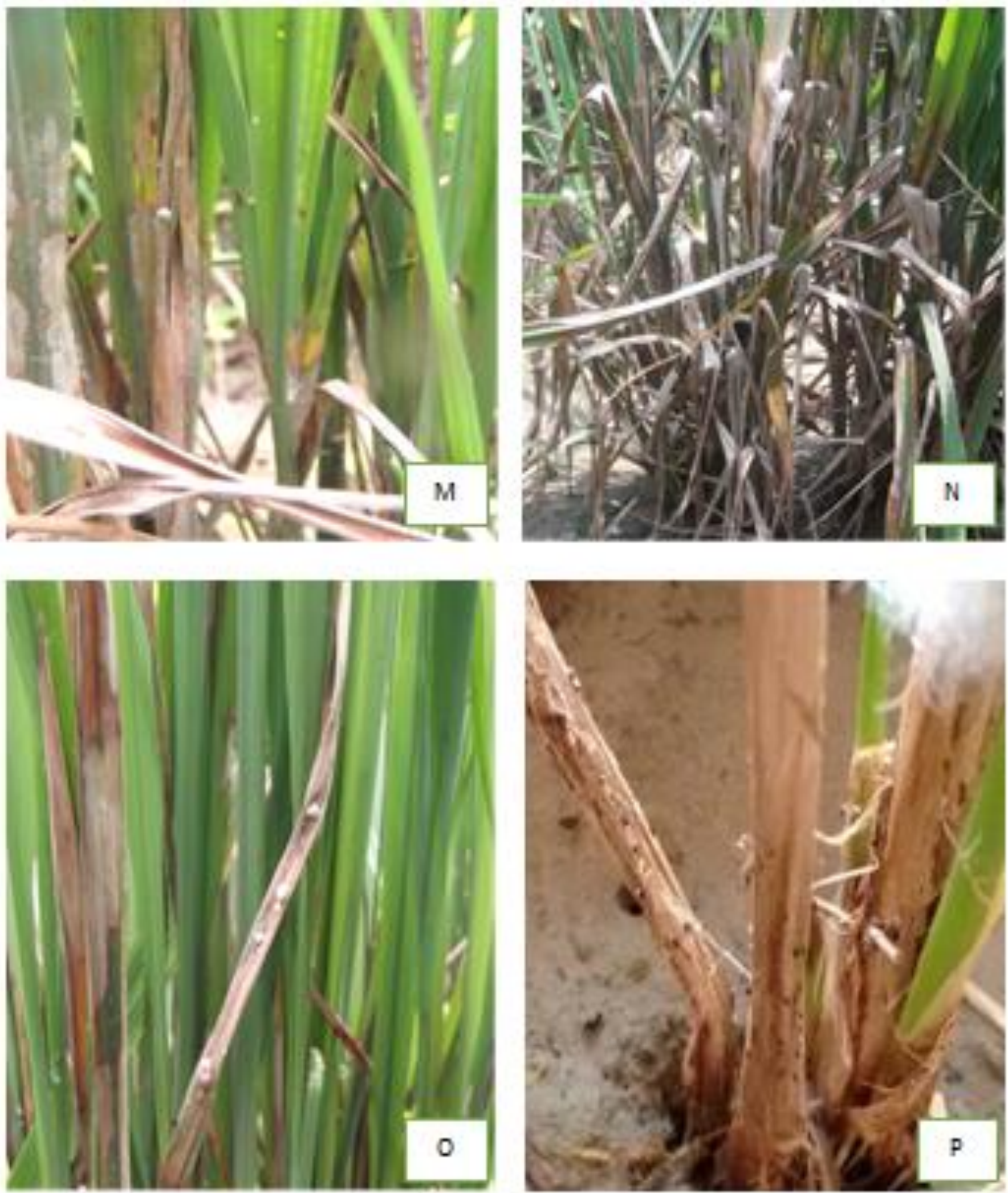
Table.1 Physiological growth stage of crop and environmental condition prevailed during the survey of different fungal disease of rice

\begin{tabular}{|c|c|c|c|}
\hline $\begin{array}{l}\text { Sl. } \\
\text { No. }\end{array}$ & $\begin{array}{c}\text { Name of the } \\
\text { pathogen/disease }\end{array}$ & $\begin{array}{l}\text { Physiological growth } \\
\text { stage of crop }\end{array}$ & Environmental condition prevails \\
\hline 1 & Blast & $\begin{array}{l}\text { Milk to Mature grain } \\
\text { stage }\end{array}$ & $\begin{array}{c}\text { Temperature ranged from } 23.88^{\circ} \mathrm{C} \text { to } \\
25.51^{\circ} \mathrm{C} \text {, Relative humidity from } 71.71 \% \text { to } \\
83.98 \%\end{array}$ \\
\hline 2 & Sheath blight & $\begin{array}{l}\text { Seedling to Dough } \\
\text { stage }\end{array}$ & $\begin{array}{c}\text { Temperature ranges } 25.21^{\circ} \mathrm{C} \text { to } 32.09^{\circ} \mathrm{C} \\
\text { Relative humidity } 82.1 \% \text { to } 97.5 \%\end{array}$ \\
\hline 3 & Sheath rot & $\begin{array}{l}\text { Booting to Dough } \\
\text { stage }\end{array}$ & $\begin{array}{c}\text { Temperature ranged from } 23.07^{\circ} \mathrm{C} \text { to } \\
26.5^{\circ} \mathrm{C} \text {, Relative humidity from } 73.85 \% \text { to } \\
87.40 \%\end{array}$ \\
\hline 4 & Brown spot & $\begin{array}{l}\text { Heading to Dough } \\
\text { stage }\end{array}$ & $\begin{array}{c}\text { Temperature ranged from } 23.79^{\circ} \mathrm{C} \text { to } \\
32.83^{\circ} \mathrm{C} \text {, Relative humidity from } 78.91 \% \text { to } \\
91.07 \%\end{array}$ \\
\hline 5 & Brown Leaf Spots & $\begin{array}{l}\text { Seedling to Booting } \\
\text { stage }\end{array}$ & $\begin{array}{c}\text { Temperature ranged from } 24.28^{\circ} \mathrm{C} \text { to } \\
33.15^{\circ} \mathrm{C} \text {, Relative humidity from } 82.91 \% \text { to } \\
98.59 \%\end{array}$ \\
\hline 6 & $\begin{array}{c}\text { Stackburn, seedling } \\
\text { blight and leaf spot of } \\
\text { rice }\end{array}$ & $\begin{array}{l}\text { Germination to } \\
\text { Tillering stage }\end{array}$ & $\begin{array}{l}\text { Temperature ranged from } 25.36 \text { to } 35.28^{\circ} \mathrm{C} \text {, } \\
\text { Relative humidity from } 85.43 \% \text { to } 99.17 \%\end{array}$ \\
\hline 7 & $\begin{array}{c}\text { Leaf spot by Nigrospora } \\
\text { oryzae }\end{array}$ & Heading to Milk stage & $\begin{array}{c}\text { Temperature ranged from } 23.51^{\circ} \mathrm{C} \text { to } \\
32.63^{\circ} \mathrm{C} \text {, Relative humidity from } 73.28 \% \text { to } \\
91.93 \%\end{array}$ \\
\hline 8 & Stem rot & $\begin{array}{l}\text { Seedling to Booting } \\
\text { stage }\end{array}$ & $\begin{array}{c}\text { Temperature ranges } 25.37^{\circ} \mathrm{C} \text { to } 32.29^{\circ} \mathrm{C} \\
\text { Relative humidity } 83.32 \% \text { to } 98.91 \%\end{array}$ \\
\hline 9 & False smut & Mature grain stage & $\begin{array}{c}\text { Temperature ranged from } 23.88^{\circ} \mathrm{C} \text { to } \\
27.51^{\circ} \mathrm{C} \text {, Relative humidity from } 71.71 \% \text { to } \\
87.84 \%\end{array}$ \\
\hline 10 & $\begin{array}{l}\text { Rotting by Choanephora } \\
\text { cucurbitarum }\end{array}$ & $\begin{array}{l}\text { Stem elongation to } \\
\text { Milk stage }\end{array}$ & $\begin{array}{c}\text { Temperature ranges } 23.85^{\circ} \mathrm{C} \text { to } 31.57^{\circ} \mathrm{C} \\
\text { Relative humidity } 78.14 \% \text { to } 94.48 \%\end{array}$ \\
\hline
\end{tabular}


Table.2 Occurrence of different fungal disease observed in different rice growing areas of Nadia district, West Bengal during Kharif 2013, 2014, 2015 and 2016 on Swarna cultivar

\begin{tabular}{|c|c|c|c|c|c|c|c|c|c|}
\hline \multirow{2}{*}{ SI no } & \multirow{2}{*}{ Disease } & \multicolumn{8}{|c|}{ Disease incidence percentage (Based on visual observation of disease leaves) } \\
\hline & & Madanpur & Jaguli & Gayeshpur & Kalyani & Chakdah & Ranaghat & Santipur & Krishnnagar \\
\hline 1. & Blast & ++ & +++ & +++ & ++++ & +++ & ++++ & +++ & +++ \\
\hline 2. & Sheath blight & +++ & ++++ & +++ & ++ & ++++ & +++ & +++ & +++ \\
\hline 3. & Sheath rot & ++ & ++++ & ++ & ++++ & +++ & ++ & +++ & ++ \\
\hline 4. & Brown spot & ++ & ++++ & ++ & ++ & ++++ & +++ & ++ & +++ \\
\hline 5. & Brown Leaf Spots & ++ & ++ & ++ & +++ & +++ & + & + & ++ \\
\hline 6. & $\begin{array}{c}\text { Stackburn, seedling blight and leaf } \\
\text { spot of rice }\end{array}$ & + & +++ & ++ & ++ & ++ & ++ & +++ & ++ \\
\hline 7. & Leaf spot by Nigrospora oryzae & + & ++ & + & + & ++ & + & + & + \\
\hline 8. & Stem rot & - & ++ & - & - & - & - & - & - \\
\hline 9. & False smut & + & +++ & + & ++ & ++ & ++ & + & + \\
\hline 10. & Rotting by Choanephora cucurbitarum & + & ++ & - & - & - & - & - & - \\
\hline
\end{tabular}


Table.3 Yield loss (\%) of Swarna cultivar due to different fungal disease in different rice growing areas of Nadia district, West Bengal during Kharif season of 2013, 2014, 2015 and 2016.

\begin{tabular}{|c|c|c|c|c|c|c|c|c|c|}
\hline \multirow{2}{*}{$\begin{array}{l}\text { Sl } \\
\text { no }\end{array}$} & \multirow[b]{2}{*}{ Disease } & \multicolumn{8}{|c|}{1000 grain weight $(\mathrm{g})$} \\
\hline & & \begin{tabular}{|c|} 
Madanpu \\
$\mathbf{r}$
\end{tabular} & $\begin{array}{c}\text { Jagul } \\
\mathbf{i}\end{array}$ & $\begin{array}{c}\text { Gayeshpu } \\
\mathbf{r}\end{array}$ & $\begin{array}{c}\text { Kalyan } \\
\text { i }\end{array}$ & $\begin{array}{c}\text { Chakda } \\
\text { h }\end{array}$ & $\begin{array}{c}\text { Ranagha } \\
\mathbf{t}\end{array}$ & $\begin{array}{c}\text { Santipu } \\
\mathbf{r}\end{array}$ & $\begin{array}{c}\text { Krishnnaga } \\
\mathbf{r}\end{array}$ \\
\hline \multirow[t]{2}{*}{1} & Blast & 33.10 & 29.00 & 27.20 & 19.17 & 28.00 & 20.10 & 26.78 & 29.13 \\
\hline & PYR (\%) & 21.38 & 32.56 & 35.84 & 54.24 & 35.18 & 52.48 & 37.86 & 33.03 \\
\hline \multirow[t]{2}{*}{2} & Sheath blight & 27.18 & 18.23 & 25.64 & 31.23 & 19.64 & 28.13 & 27.40 & 28.11 \\
\hline & PYR (\%) & 35.43 & 57.60 & 39.52 & 25.46 & 54.53 & 33.49 & 36.42 & 35.37 \\
\hline \multirow[t]{2}{*}{3} & Sheath rot & 33.10 & 19.20 & 30.10 & 18.90 & 25.14 & 30.40 & 27.18 & 32.10 \\
\hline & PYR (\%) & 21.38 & 55.34 & 29.00 & 54.89 & 41.80 & 28.13 & 36.93 & 26.20 \\
\hline \multirow[t]{2}{*}{4} & Brown spot & 29.13 & 18.20 & 33.10 & 32.21 & 19.90 & 26.10 & 31.10 & 27.90 \\
\hline & PYR (\%) & 30.80 & 57.67 & 21.93 & 23.12 & 53.93 & 38.29 & 27.84 & 35.86 \\
\hline \multirow[t]{2}{*}{5} & Brown Leaf Spots & 30.10 & 31.80 & 30.90 & 27.60 & 26.89 & 36.70 & 37.80 & 31.20 \\
\hline & PYR (\%) & 28.50 & 26.04 & 27.12 & 34.12 & 37.75 & 13.23 & 12.29 & 28.27 \\
\hline \multirow[t]{2}{*}{6} & Stackburn, seedling blight & 37.18 & 22.30 & 29.10 & 28.36 & 28.10 & 29.01 & 20.18 & 29.18 \\
\hline & PYR (\%) & 11.69 & 48.13 & 31.36 & 32.31 & 34.95 & 31.41 & 53.17 & 32.91 \\
\hline \multirow[t]{2}{*}{7} & Leaf spot by Nigrospora oryzae & 38.10 & 32.40 & 37.30 & 38.10 & 31.90 & 38.40 & 38.30 & 37.40 \\
\hline & PYR (\%) & 9.50 & 24.65 & 11.32 & 9.06 & 26.15 & 9.21 & 11.13 & 14.02 \\
\hline \multirow[t]{2}{*}{8} & Stem rot & - & 30.38 & - & - & - & - & - & - \\
\hline & PYR (\%) & - & 29.34 & - & - & - & - & - & - \\
\hline \multirow[t]{2}{*}{9} & False smut & 36.90 & \begin{tabular}{|l|}
19.10 \\
\end{tabular} & 35.10 & 28.90 & 27.68 & 29.30 & 37.10 & 36.39 \\
\hline & PYR (\%) & 12.35 & 55.58 & 17.21 & 31.02 & 35.92 & 12.29 & 32.01 & 16.34 \\
\hline \multirow[t]{2}{*}{10} & $\begin{array}{c}\text { Rotting by Choanephora } \\
\text { cucurbitarum }\end{array}$ & 36.30 & 29.13 & - & - & - & - & - & - \\
\hline & PYR (\%) & 13.77 & 32.25 & - & - & - & - & - & - \\
\hline
\end{tabular}

$\mathrm{PYR}=$ Percentage Yield Reduction 
Physiological growth stage of the crop and Environmental conditions prevailed during monitoring and surveillance

The investigation (Table 1) based on blast of rice reveals that the incidence favours Milk to Mature grain stage of rice with Temperature ranged from $23.88^{\circ} \mathrm{C}$ to $25.51^{\circ} \mathrm{C}$ and Relative humidity from $71.71 \%$ to $83.98 \%$. Castejon (2008) reported that a relative humidity of 95 per cent and an average temperature of 26$27^{\circ} \mathrm{C}$ were optimum for infection and substantially favoured spore release. Incidence of sheath blight favours Seedling to Dough stage and biometeorological parameters reveals that, the Temperature $25.21^{\circ} \mathrm{C}$ to $32.09^{\circ} \mathrm{C}$, Relative humidity 82.1 $\%$ to $97.5 \%$ during the infestation. Pasalu et al., (2005) Relative humidity and temperature are limiting factors for sheath blight infection and therefore the infestation is more common in wet season as compare to dry season. Infestation of sheath rot was recorded during Booting to Dough stage when, Temperature and Relative humidity ranged from $23.07^{\circ} \mathrm{C}$ to $26.5^{\circ} \mathrm{C}$, from $73.85 \%$ to $87.40 \%$ respectively. Sakthival, (2001) also recorded that, the temperature ranges between $20^{\circ} \mathrm{C}$ $30^{\circ} \mathrm{C}$ and relative humidity $65 \%-80 \%$ favours sheath rot infestation. The severity of brown spot was recorded maximum during Heading to Dough stage when, Temperature ranged from $23.79^{\circ} \mathrm{C}$ to $32.83^{\circ} \mathrm{C}$ and Relative humidity from $78.91 \%$ to $91.07 \%$. Katsura in 1937 also detected that, at $25^{\circ} \mathrm{C}$ temperature and relative humidity of over $89 \%$ is required for successful inoculation by conidia of Cochliobolus miyabeanus. Severe infestation of brown leaf spot was observed during Seedling to Booting stage when temperature and relative humidity recorded $24.28^{\circ} \mathrm{C}$ to $33.15^{\circ} \mathrm{C}$ and $82.91 \%$ to $98.59 \%$ respectively. Some earlier researchers (Martyn, 1936) also recorded severe infection of Curvularia lunata during a wet season. Severity of Stackburn infestation was prominent during
Germination to Tillering stage when, Temperature ranged from 25.36 to $35.28^{\circ} \mathrm{C}$, Relative humidity from $85.43 \%$ to $99.17 \%$. Some earlier researchers also testified that the stack burn disease is probable to develop in wet season when, the rice remains in the field and stack do not dry out (Tisdale, 1922). Maximum incidence of Nigrospora oryzae was recorded during Heading to Milk stage when, prevailing Temperature was from $23.51^{\circ} \mathrm{C}$ to $32.63^{\circ} \mathrm{C}$ and Relative humidity from $73.28 \%$ to $91.93 \%$. Kimura, (1937) recorded that the inoculation of Nigrospora oryzae before flowering stage consequences more grain discoloration. The severe infection of stem rot of rice was favoured at Temperature $25.37^{\circ} \mathrm{C}$ to $32.29^{\circ} \mathrm{C}$ and Relative humidity $83.32 \%$ to $98.91 \%$ during Seedling to Booting stage. Temperature from $23.88^{\circ} \mathrm{C}$ to $27.51^{\circ} \mathrm{C}$ and Relative humidity from $71.71 \%$ to $87.84 \%$ during Mature grain stage Was favourable for the false smut of rice. Yasoda et al., (2000) reported that medium temperature, cloudy weather with high humidity caused tremendous loss in rice production due to false smut caused by Ustilaginoidea virens. Rotting by Choanephora cucurbitarum was recorded maximum when, Temperature ranges $23.85^{\circ} \mathrm{C}$ to $31.57^{\circ} \mathrm{C}$ and Relative humidity $78.14 \%$ to $94.48 \%$ during Stem elongation to Milk stage. Umana and Ikotoun, (2000) reported that the fungus was more successful during humid condition and thrives best at temperature $25^{\circ} \mathrm{C}$ and high humidity.

Test weight (g) and percentage yield reduction (\%) Swarna cultivar due to different fungal foliar diseases on different locations of rice growing areas

From table 2 it is observed that Leaf blast was noticed in mild form at Madanpur, moderate at Jaguli, Gayeshpur, Chakdah, Santipur and Krishnagar and severe at Kalyani and Ranaghat during Kharif 2013, 2014, 2015 and 
2016. Sheath blight was noticed in severe form at Jaguli and Chakdah. Among eight spots, the disease incidence of sheath rot was recorded maximum at Jaguli and Kalyani while moderate infection was observed at Chakdah and Santipur. Brown spot was more severe at Chakadah and Jaguli. Among all eight locations, Brown Leaf Spots caused by Curvularia lunata was found to be moderate at Kalyani and Chakadah. Stackburn disease was to be moderate at Jaguli and Santipur. Mild and trace infection was recorded due to Leaf spot caused by Nigrospora oryzae, stem rot and rotting caused by Choanephora cucurbitarum and the false smut was more severe at Jaguli. Among all the ten foliar fungal diseases (Table 3), blast caused severe (> 45\%) yield losses and the intensity of yield loss was maximum at Kalyani (54.24\%) and Ranaghat (52.48\%). Whereas, the severe yield losses caused by other foliar fungal disease were as follow:

Sheath blight was causing severe yield losses at Jaguli (57.60\%) and Chakdah (54.53\%).

Sheath rot was causing more yield losses at Jaguli (55.34\%) and Kalyani (54.89\%).

Brown spot was found severe at Jaguli (57.67\%) and Chakadah (53.93\%).

Stackburn were found severe at Jaguli $(48.13 \%)$ and Santipur (53.17\%).

False smut was more severe at Jaguli $(55.88 \%)$.

\section{References}

Anonymous, 2013. World rice production in metric tonnes. Food and Agriculture Organization of the United Nations. www.geohive.com/charts/ag_rice.aspx.

Castejon, M.M., 2008. The effect of temperature and relative humidity on the airbone concentration of Pyricularia oryzae spores and the development of rice blast in southern Spain. Spanish Journal of Agricultural Research 6:6169.

Gupta, A.K., Solanki IS, Bashyal BM, Singh Y. and Srivastava K. 2015. Bakanae of rice-an emerging disease in Asia. The Journal of Animal \& Plant Sciences. 25(6): 1499-1514.

Hajano, J., Pathan MA, Rajput Q.A., and Lodhi MA. 2011. Rice blast-mycoflora, symptomatology and pathogenicity. International Journal for Agro Veterinary and Medical Sciences 5: $53-63$.

IRRI. 1996. Standard Evaluation System for rice. INGER Genetic Resource Centre, 4th Edn. July.

Katsura, K., 1937. On the relation of atmospheric humidity to the infection of the rice plant by Ophiobolus miyabeanus and to the germination of its conida. ibid 7: 105-24.

Kimura, K., 1937. On the relation of fungi to discoloured rice seeds. Forch Reflator Kyoto 3: 209-233.

Martyn, E.B., 1936. Report on the botanical and mycological division for the year, 1935. Divisional reports of the Department of Agriculture, British Guiana. 89-92.

Pasalu, I.C., Katti G, Krishnamurthy P, Subba Rao LV, Reddy CS, Subbaiah SV, Krishnaiah N V. and Prasad JS. 2005. Integrated pest management in rice. Technical bulletin no. 15. Directorate of rice research, Rajendranagar, Hyderabad, AP, India. pp.53.

Ravat, V.K., Roy S. and Basu A. 2015. Rice: A new host of Choanephora cucurbitarum in West Bengal. Annals of Plant Protection Sciences 23(1): 158199.

Sakthivel, N., 2001. "Sheath rot disease of rice: current status and control 
strategies," in Major Fungal Diseases of Rice: Recent Advances eds Sreenivasaprasad S., Johnson R., editors. (Dordrecht: Springer) 271-283.

Tisdale, W.H., 1922. Seedling blight and stack-burn of rice and the hot-water seed treatment. Bulletin of the United States Department of Agriculture No. 1116, USDA, Washington, DC., USA., November 13, 1922, pp.: 1-11.

Umana, E.J., and Ikotun T. 2000. Effect of pH on enzyme productivity of three pathotype of Choanephora cucurbitarum. Global Journal of Pure and Applied science. 6(3): 413- 418.

Wheeler, B.E.J., 1969. An introduction to plant diseases. John Wiley and Sons Ltd., London.

Yashoda, H., Anahosur KK, Kulkarni S, Yashoda H. and Anahosur KH. 2000. Influence of weather parameters on incidence of false smut of rice. Advanced Agriculture Research India 14:161- 165 .

\section{How to cite this article:}

Vikas Kumar Ravat and Amitava Basu. 2017. Current Status of Fungal Diseases on Swarna Cultivar (MTU 7029) of Rice in Gangetic Alluvial Zone of West Bengal, India. Int.J.Curr.Microbiol.App.Sci. 6(9): 2069-2080. doi: https://doi.org/10.20546/ijcmas.2017.609.254 